Ege Tıp Dergisi / Ege Journal of Medicine 2019; 58 (4): 397-405

\title{
Mikroalbüminürisi olan ve olmayan tip 2 diyabetik hastalarda serum asimetrik dimetil arjinin, fetuin-A ve ankle-brakial indeks değerlerinin değerlendirilmesi
}

The evaluation of serum asymmetric dimethyl arginine, fetuin- $A$ and ankle-brachial index values in type 2 diabetic patients with and without microalbuminuria

\author{
Aslı Kılavuz ${ }^{1}$ \\ Bakiye Göker ${ }^{2}$ D \\ Sumru Savaş ${ }^{1}$ iD \\ Çığır Biray $\mathrm{Avcı}^{2}$ ib \\ Fulden Saraç ${ }^{1}$ (D) \\ Cumhur Gündüz $z^{2}$ \\ ${ }^{1}$ Ege Üniversitesi Tıp Fakültesi, İç Hastalıkları Anabilim Dalı, İzmir, Türkiye \\ ${ }^{2}$ Ege Üniversitesi Tıp Fakültesi, Tıbbi Biyoloji Anabilim Dalı, İzmir, Türkiye
}

Öz

Amaç: Çalışmamızda mikroalbüminürisi olan ve olmayan tip 2 diabetes mellituslu hastalarda ateroskleroz belirteçlerini karşılaştırmayı amaçladık.

Gereç ve Yöntem: Bu çalışmaya 40-60 yaşları arasında, tip 2 diyabetli mikroalbüminürik ve mikroalbuminürisi olmayan 80 hasta dahil edildi. Hastaların serum asimetrik dimetil arjinin, fetuin-A düzeyleri, lipit profili ile açlık ve tokluk glukoz, A1c gibi laboratuvar parametreleri değerlendirildi. Anklebrakiyal indeks (ABI) ölçümleri yapıldı.

Bulgular: Mikroalbüminüri ile total kolesterol, trigliserid, LDL kolesterol, HDL kolesterol, A1c, plazma açlık glukozu, vücut kitle indeksi, ankle-brakiyal indeksi arasında istatistiksel olarak anlamlı bir ilişki bulunmadı. mikroalbüminürisi olan hastalar mikroalbüminürisi olmayan hastalara göre anlamlı olarak daha düşük serum fetuin-A düzeylerine sahipti $(p=0,008)$. Ancak, fetuin-A düzeyleri ve mikroalbüminüri arasında anlamlı negatif korelasyon elde edildi. Düşük fetuin-A düzeylerinin, $A B \mid \leq 0,9$ olarak tanımlanan periferik arter hastalığı ile ilişkili olduğu belirlendi $(p=0,001)$. Mikroalbüminüri ve serum asimetrik dimetil arjinin düzeyleri arasında istatistiksel olarak anlamlı ilişki saptandı. Mikroalbüminürisi olan hastaların, olmayanlara göre anlamlı olarak daha yüksek serum asimetrik dimetil arjinin düzeylerine sahip olduğu belirlendi $(p=0,013)$.

Sonuç: Çalışmamızın sonuçlarına göre, aterosklerotik süreçte tip 2 diabetes mellituslu mikroalbüminürisi olan hastalarda serum asimetrik dimetil arjininin fetuin-A'ya üstün olduğu ileri sürülebilir.

Anahtar Sözcükler: Diabetes mellitus tip 2, serum asimetrik dimetil arjinin, fetuin-A, ankle-brakiyal indeks, mikroalbüminüri.

\footnotetext{
Abstract without microalbuminuria. measured. with subjects of non-microalbuminuria $(p=0.008)$.

Yazışma Adresi: Aslı Kılavuz

Ege Üniversitesi Tıp Fakültesi, İç Hastalıkları AD, İzmir, Türkiye

E-mail: asli.kilavuz@ege.edu.tr

Makalenin Geliş Tarihi: 09.11.2018 Kabul Tarihi: 14.01.2019
}

Aim: We aimed to compare atherosclerosis markers in patients with type 2 diabetes mellitus with and

Material and Methods: Eighty type 2 diabetes mellitus patients with and without microalbuminuria aged between 40-60 years were enrolled in this study. Serum levels of asymmetric dimethylarginine, fetuin- $A$ and laboratory parameters such as lipid profile and A1c were evaluated. Ankle-brachial indexes were

Results: No statistically significant correlation was found between microalbuminuria and total cholesterol, triglyceride, LDL cholesterol, HDL cholesterol, A1c, plasma fasting glucose, body mass index, anklebrachial index. Patients with microalbuminuria had significantly lower serum fetuin-A levels in comparison 
However, a significant negative correlation was achieved between fetuin- $A$ levels and microalbuminuria. We found that lower fetuin-A levels were associated with peripheric arterial disease, defined as anklebrachial index $\leq 0.9(p=0.001)$. There was a statistically significant correlation between microalbuminuria and serum asymmetric dimethylarginine levels. Patients with microalbuminuria had significantly higher serum asymmetric dimethylarginine levels in comparison with subjects with non-microalbuminuria $(p=0.013)$.

Conclusion: Based on our results, it can be suggested that serum asymmetric dimethyl arginine is superior to fetuin-A in patients with type 2 diabetes mellitus and microalbuminuria for atherosclerotic process.

Keywords: Diabetes mellitus type 2, serum asymmetric dimethylarginine, fetuin-A, ankle-brachial index, microalbuminuria.

\section{Giriş}

Diabetes mellitus (DM) yetişkinlerde son dönem böbrek yetmezliği, körlük, travmatik olmayan alt ekstremite amputasyonlarının en sık nedenidir. Bu komplikasyonların hepsi ilerleyici aterosklerozdan kaynaklanmaktadır (1). Tip 2 diabetes mellituslu (T2DM) hastalarda, mikro ve makrovasküler riski tanımlamak için inflamatuar, metabolik ve prokoagülan moleküllerle ilgili birçok çalışma yapılmıştır (2-4). Bunlardan biri, erken diyabetik nefropatinin belirleyicisi olan, sistemik vasküler hasar, geniş endotel disfonksiyonu ve renal fonksiyondan bağımsız olarak artmış ateroskleroz riskini gösteren albüminüridir (5-7).

Arteriyel hastalığı olan hastanın değerlendirilmesi kapsamlı bir öykü ve fizik muayene ile başlar ve invaziv olmayan vasküler çalışmalar klinik tanıyı teyit etmek için ek olarak kullanır ve vasküler patolojinin seviyesini ve kapsamını daha iyi tanımlar. Arteriyel hastalık düşündüren semptomları (örn.: intermittant kladikasyo), fizik muayene bulguları (örn.: doku iskemisi bulguları), ateroskleroz için risk faktörü (örn.: sigara içimi, diabetes mellitus) veya diğer arteriyel patolojisi olan hastalarda (örn.: travma, periferik emboli) vasküler test yapılabilir (8). Ankle-brakiyal indeks $(A B I)$, periferik arter hastalığının $(P A H)$ ciddiyetini ölçmek için kullanılan basit ve ucuz bir yöntemdir. $\mathrm{Bu}$ nedenle diyabetik hastalarda $\mathrm{PAH}$ 'yi taramak için yaygın olarak kullanılmaktadır $(8,9)$.

Karaciğerde üretilen ve seruma yüksek konsantrasyonda salınan bir glikoprotein olan fetuin-A (10), karaciğer dışında böbreklerde, koroid pleksus ve bütün büyük organlarda fetal gelişim süresince sentezlenebilen yeni bir ateroskleroz belirtecidir. Fetuin-A; kalsiyum ve fosfat içeren aşırı doymuş solüsyonda spontan hidroksiapatit oluşumunun güçlü bir inhibitörüdür (11). İnsanlarda fetuin-A sekresyonunu etkileyen faktörler arasında; şiddetli karaciğer hasarı, siroz, akut viral hepatit ve kanser gibi durumlar bildirilmiştir. Hepatit hariç bu hastalıklara sahip bireylerde fetuin-A plazma düzeyleri azalmıştır. Fetuin-A'nın in vitro ve hayvan çalışmalarında insülin direnci için önemli olduğu bulunmuştur. İnsan rekombinant fetuin-A'nın akut enjeksiyonunun rat karaciğer ve iskelet kasında insülin sinyalizasyonunu inhibe ederek aterosklerozun başlamasına yol açan insülin direncini uyardığı bildirilmiştir. Ayrıca, kemik remodellingi ve kalsiyum metabolizmasını düzenler, adipojenik özellikleri vardır. Bu yüzden karaciğerde yağ depolanması fetuin-A'nın yüksek düzeyleriyle ilişkili olabilir (12). Fetuin-A'nın yüksek düzeyleri obezite, metabolik sendrom, T2DM, nonalkolik yağlı karaciğer hastalığı, iskemi ve miyokardiyal infaktüs ile ilişkili bulunmuştur (13). Periferik arter hastalığı olan diyabetli hastalarda fetuin-A'nın rolü ile ilgili çelişkili sonuçlar mevcuttur $(3,4,14)$.

Serum asimetrik dimetil arjinin (ADMA), endojen kompetitif nitrik oksit sentaz inhibitörüdür. Yüksek kardiyovasküler riskli hastalarda düzeyi artmıştır ve gelecek kardiyovasküler olayları uyarır. Farmakolojik düzeylerde hipertansiyon, kardiyak disfonksiyon ve renal fonksiyon bozukluğuna sebep olur. Dimetil arjinin dimetil amino hidrolaz tarafından metabolize edilir veya böbreklerden salgılanır. Asimetrik dimetil arjinin ve steroizomeri simetrik dimetil arjininin nitrik oksit sentaza direkt etkisi yoktur, böbrek yetmezliği olan hastalarda birikir. Kronik böbrek hastalığında aterosklerozu uyarabilir ve tip 1 DM'li ve makroalbuminürili hastalarda makrovasküler hastalıklar ile ilişkilidir (15).

Albüminüri kardiyovasküler hastalık için T2DM'li hastalarda tip 1 DM'li hastalardan daha güçlü bir risk faktörüdür. Krzyzonowska ve arkadaşlarının yaptıkları bir çalışmada T2DM'li, belirgin veya 
başlangıç aşamasında diyabetik nefropatisi olan hastalarda ADMA, albüminüri gibi güçlü bir risk faktörü olarak belirlenmiş̧ir. Bu yeni risk markerinin albüminüri, yüksek sensitif $\mathrm{C}$-reaktif protein ve kardiyovasküler mortalitenin var olan risk prediktörleri ile ilişkili olduğu gösterilmiştir (15).

$\mathrm{Bu}$ çalışmanın amacı, mikroalbüminürisi (MAÜ) olan ve olmayan T2DM'li hastalarda ateroskleroz belirteçleri olan serum ADMA, fetuin-A düzeyleri ve $A B \mid$ değerlerini karşılaştırmak ve T2DM ve MAÜ'lü hastalarda bu belirteçlerin aralarındaki ilişkiyi araştırmaktır.

\section{Gereç ve Yöntem}

\section{Hasta popülasyonu}

Çalışmaya Ocak-Haziran 2016 tarihleri arasında İzmir'de bir üniversite hastanesi İç Hastalıkları polikliniğine başvuran 40-60 yaşları arasındaki 80 T2DM hastası dahil edildi. Diyabet durumu tıbbi kayıtlar ve kullandıkları antidiyabetik ilaç tedavileri gözden geçirilerek belirlendi.

Malignite, bağ dokusu hastalığı, gebelik, idrar yolu enfeksiyonu, inflamatuar hastalık, idrarda kreatinin atıımını etkileyebilen ilaç kullanımı, VKI $>35 \mathrm{~kg} / \mathrm{m} 2$ olan, orta veya şiddetli böbrek hastalığı (kreatinin klirensi $<45 \mathrm{ml} / \mathrm{dk}$ ) olan, geçirilmiş koroner by-pass ameliyatı veya alt ekstremite arterlerine perkütan anjiyoplasti uygulanmış ve akut ekstremite iskemisi olan hastalar çalışma dışında bırakıldı. Hastalar her grupta 40'ar hasta olmak üzere MAÜ olan ve olmayan iki gruba ayrıldı.

Çalışmamız için yerel etik kurul onayı alındı ve tüm araştırmalar Helsinki Bildirgesi ilkelerine uygun olarak gerçekleştirildi. Çalışmanın amacı tüm katılımcılara açık bir şekilde açıklandı ve yazılı bilgilendirilmiş onam alındı.

\section{Yöntem}

Çalışmamız kesitsel bir çalışmadır. Tüm biyokimyasal ölçümler 10-12 saat açlık sonrası, sabah yapıldı. Hastaların antidiyabetik veya diğer ilaçlarını muayenenin sonunda ve kan örneklemesinden sonra alması sağlandı. Kan örnekleri antekubital venden alındı, hemen santrifüj edildi ve $-80^{\circ} \mathrm{C}$ 'de donduruldu.

Hastalara kapsamlı fizik muayene yapıldı. Mevcut ve önceki hastalıkları, sigara içme alışkanlıkları, alkol alımı, diyabet süresi ve mevcut ilaçların kullanımı ile ilgili ayrıntılı bir sorgulama yapıldı. Her hastanın boy ve vücut ağırlığı ölçüldükten sonra VKI hesaplandı.
Hipertansiyon mevcut kılavuzlara göre tanımlandı. Sistolik kan basıncı $\geq 140 \mathrm{mmHg}$ ve/veya diyastolik kan basıncı $\geq 90 \mathrm{mmHg}$ olan ve/veya antihipertansif tedavi alan hastalar hipertansif olarak kabul edildi (16). Dislipidemi, lipit düşürücü ilaçların kullanımı ve/veya LDL kolesterol düzeyi $\geq 130 \mathrm{mg} / \mathrm{dl}$ ve/veya total kolesterol düzeyi $\geq 200 \mathrm{mg} / \mathrm{dl}$ ve/veya trigliserit düzeyi $\geq 150 \mathrm{mg} / \mathrm{dl}$ ve/veya HDL kolesterol düzeyi kadınlarda $<50 \mathrm{mg} / \mathrm{dl}$, erkeklerde $<40 \mathrm{mg} / \mathrm{dl}$ olarak tanımlandı (17).

\section{ABI ölçümü}

Brakiyal arter basınçları, yatar pozisyonda her iki üst ekstremiteden bir tansiyon aleti yardımı ile ölçüldü. Bilateral ayak bileği basınçları (dorsalis pedis ve posterior tibial arter), $8 \mathrm{mHz}$ 'lik probu olan elde tutulan bir Doppler cihazı kullanılarak ölçüldü. Ankle-brakiyal indeks, alt ve üst ekstremitelerde sistolik kan basınçlarının oranı olarak aşağıda gösterilen formül ile hesaplandı.

$[A B \mid=$ Daha yüksek olan ayak bileği basıncı (dorsalis pedis veya posterior tibial arter) / Daha yüksek olan brakiyal sistolik basınç].

Amerikan Diyabet Cemiyetinin yaptığı sınıflamaya göre, üç $A B \mid$ i grubu tanımlandı: düşük $(A B \mid \leq 0.90)$, normal $(0.90<A B \mid<1.30)$ ve yüksek $(A B \mid \geq 1.30)$ (18).

\section{Fetuin-A, ADMA ve diğer biyokimyasal ölçümler}

Serum separatör jel tüplerindeki 4 mililitre kan örnekleri, serum elde etmek için 3000 rpm'de 10 dakika santrifüj edildi. Fetuin-A ve ADMA düzeylerini belirlemek için Enzyme-Linked ImmunoSorbent Assay (ELISA) yöntemi kullanıldı. Fetuin-A ve ADMA seviyelerini belirlemek için sırasıyla fetuin-A ELISA (BioVendor, Çek Cumhuriyeti) ve ADMA ELISA (BioVendor, Germany) kitleri kullanıldı. Her bir analiti belirlemek için her numunenin 200 mikro litresi kullanıldı. Numunelerin miktar tayini için her iki analizde de sabit konsantrasyonlara, yüksek pozitif kontrollere ve negatif (boş) kontrole sahip altı standart kullanıldı. Test prosedürleri, kullanım kılavuzlarında açıklandığı şekilde gerçekleştirildi. Okumalar, $450 \mathrm{~nm}$ dalga boyunda ve $630 \mathrm{~nm}$ referansta bir Multiskan FC (Thermo) cihazı kullanılarak yapıldı. Her bir deney üç kopya halinde gerçekleştirildi. Sonuçların istatistiksel değerlendirmesi için SPSS yazılımı kullanıldı. Aynı deneyimli araştırmacı tarafından fetuin-A ve serum ADMA düzeylerinin ölçümleri yapıldı.

Açlık kan glukozu (AKG, mg/dL), total kolesterol (mg/dL), HDL kolesterol, LDL kolesterol ( $\mathrm{mg} / \mathrm{dL})$, trigliserid $(\mathrm{mg} / \mathrm{dL})$, A1c (\%) seviyeleri ve idrar 
mikroalbumin-kreatinin oranı, hastalardan serum fetuin-A ve ADMA düzeylerinin ölçümü için kan alındığı gün hasta elektronik dosyalarından geriye dönük olarak kaydedildi. Serum açlık glukozu, total kolesterol, HDL kolesterol, LDL kolesterol, trigliserid düzeyleri hastaların venöz kan örneğinden elde edilen serumdan otomatik analizörde ölçüldü. A1c analizi, IFCC tarafından onaylanan immunotürbidimetrik yöntemle ve ticari kit (Roche Diagnostics, Germany) kullanılarak otoanalizörde (Roche Cobas 502, USA) çalışıldı. A1c düzeyleri \%7'nin üzerinde yüksek olarak değerlendirildi. İdrar mikroalbümin-kreatinin oranı için sabah alınan spot idrar örneğinde kolorimetrik yöntemle otoanalizörde (Roche Cobas 702, USA) albümin ve kreatinin çalışıldı. Kreatininle düzeltilmiş (mikroalbüminx1000/kreatinin) albüminüri (UACRUrine Albumin-to-Creatinin Ratio) formülüne göre; $0-20 \mathrm{mg} / \mathrm{g}$ arası normal, $20-300 \mathrm{mg} / \mathrm{g}$ arası mikroalbüminüri, $>300 \mathrm{mg} / \mathrm{g}$ ise makroalbüminüri olarak değerlendirildi.

Istatistiksel analiz

Tüm istatistiksel analizler SPSS 18.0 istatistik paketi (SPSS, Inc., Chicago, IL, ABD) kullanılarak yapıldı. Tüm veriler değerlerinin normal dağılımı için değerlendirildi. Parametreler ortalama \pm standart sapma (SD) veya sayı olarak (\%) olarak sunuldu. Kategorik değişkenler Ki-kare testi ve/veya Fisher'in kesin testi ile karşılaştırıldı. Normal dağılmış verilerden oluşan gruplar arasındaki karşılaştırmalar, bağımsız örneklem Student-t testi veya tek yönlü varyans analizi ile gerçekleştirildi. Mikroalbüminüri ile, çalışılan parametreler arasındaki ilişkiyi araştırmak için tek değişkenli lojistik regresyon analizleri (kademeli olarak geriye doğru yöntem) gerçekleştirildi. P $<0,05$ ise fark anlamlı kabul edildi.

\section{Bulgular}

Tip 2 DM'li, 42 kadın ve 38 erkek toplam 80 hasta çalışmaya dahil edildi. Hastalar iki gruba ayrıldı: T2DM ve MAÜ'lü katılımcılar, T2DM olan ancak MAÜ'sü olmayan katııımcılar. Çalışma katıımcılarının başlangıç özellikleri Tablo-1'de sunulmuştur.

Mikroalbüminürisi olmayan hastaların yaş ortalaması $52,58 \pm 6,13(40-60)$ yıl ve MAÜ'lü hastaların yaş ortalaması $53,98 \pm 6,02(40-60)$ yıl idi. Çalışma grupları arasında yaş ve cinsiyet dağılımı açısından fark saptanmadı.

Ankle-brakiyal indeks değerleri açısından: MAÜ olan 40 hastanın dördünde (\%10) $\mathrm{ABI}$ değeri $\leq 0,90 ; 31$ hastada $(\% 77,5) \quad 0,91-1,30$; ve beş hastada $(\% 12,5) \quad \geq 1,30 ; \quad$ MAÜ olmayan 40 hastadan üçünde $(\% 7,5)$ ABI değeri $>1,30 ; 37$ hastada ise normal $(0,91-1,30)$ idi.

Mikroalbüminürili hastaların MAÜ olmayanlara göre daha düşük serum fetuin-A düzeylerine sahip oldukları belirlendi (sırasıyla 368,06 $\pm 68,45 \mathrm{mg} / \mathrm{L}$, $441,33 \pm 115,38 \mathrm{mg} / \mathrm{L})(p=0,008)$ (Tablo-1, Şekil1) Düşük fetuin-A düzeylerinin $A B \mid \leq 0,9$ olarak tanımlanan $\mathrm{PAH}$ ile ilişkili olduğunu saptandı $(p=0,001)$.

Mikroalbüminürili hastaların MAÜ olmayanlara göre anlamlı olarak daha yüksek serum ADMA seviyelerine sahip oldukları belirlendi (sırasıyla $0,66 \pm 0,20 \mu \mathrm{mol} / \mathrm{L}, 0,53 \pm 0,15 \mu \mathrm{mol} / \mathrm{L})(p=0,013)$ (Tablo-1, Şekil-2). Ankle-brakiyal indeks ve ADMA seviyeleri arasında anlamlı bir ilişki saptanmadı $(p=0,21)$.

Mikroalbüminürili dokuz hasta $(\% 22,5)$ ve MAÜ olmayan 11 hasta $(\% 27,5)$ sigara içiyordu. Mikroalbüminüri ile sigara içme arasında istatistiksel olarak anlamlı bir ilişki saptanmadı $(p=0,87)$.

A1c değerleri MAÜ'lü 24 hastada $(\% 60)$ ve MAÜ olmayan 19 hastada $(\% 47,5), \geq \% 7(53 \mathrm{mmol} / \mathrm{mol})$ idi. MAÜ varlığında yüksek $\mathrm{A} 1 \mathrm{c}$ değerlerine rağmen, MAÜ ve A1c düzeyleri arasında istatistiksel olarak anlamlı bir ilişki bulunmadı $(p=0,5)$.

Tip 2 DM ve MAÜ'lü hastalar daha uzun diyabet süresine sahipti ve MAÜ olmayan hastalar ile karşılaştırıldığında dislipidemi, hipertansiyon ve fazla kilolu hasta oranı daha yüksek saptandı.

Mikroalbüminürili olan ve olmayan hastalarda diyabetin ortalama süresi sırasıyla $144 \pm 17,18$ ay $($ medyan $=120)$ ve $92,05 \pm 11,97$ ay (medyan $=$ $60)$ idi. Mikroalbüminüri ile diyabet süresi arasında istatistiksel olarak anlamlı bir ilişki saptandı $(p=$ $0,04)$. Diyabet süresi arttıkça, MAÜ oranının arttığı görüldü.

Hastaların oral antidiyabetik ilaç, insülin ve oral antidiyabetik ilaç+insülin kombinasyonu kullanım oranları sırasıyla \%47,5 ( $n=19), \% 5(n=2)$ ve $\% 47,5(n=19)$ olarak saptandı. Kullanılan ilaç tipi ile MAÜ arasında istatistiksel olarak anlamlı bir ilişki bulunmadı $(p=0,10)$.

İki grup arasında $A K G$, lipit parametreleri, $A B \dot{I}$ değerleri, VKI, hipertansiyon, sigara ve alkol tüketimi açısından anlamlı fark saptanmadı. 
Tablo-1. MAÜ varlığına göre çalışma popülasyonunun karakteristikleri.

\begin{tabular}{|c|c|c|c|}
\hline Karakteristikler & MAÜ (+) & MAÜ (-) & p \\
\hline Kadın, n (\%) & $20(50)$ & $22(55)$ & 0,82 \\
\hline Yaş $^{\mathrm{a}}(\mathrm{y} ı \mathrm{I} \pm S D)$ & $53,98 \pm 6,02$ & $52,58 \pm 6,13$ & 0,21 \\
\hline Sigara, n (\%) & $9(45)$ & $11(55)$ & 0,87 \\
\hline Alkol, n (\%) & $1(33,3)$ & $2(66,7)$ & 1,00 \\
\hline Diyabet süresi (ay) & $\begin{array}{l}144 \pm 17,18 \\
(\text { medyan }=120)\end{array}$ & $\begin{array}{l}92,05 \pm 11,97 \\
(\text { medyan }=60)\end{array}$ & $0,04^{*}$ \\
\hline HT, n (\%) & $25(56.8)$ & $19(43,2)$ & 0,26 \\
\hline VKi $\left(\mathbf{k g} / \mathbf{m}^{2}\right)$ & $30,80 \pm 1,35(23,12-40,23)$ & $29,80 \pm 0,61(17,36-70,98)$ & 0,55 \\
\hline$A B \dot{i}$ & $1,14 \pm 0,17(0,86-1,60)$ & $1,12 \pm 1,06(1,00-1,44)$ & 0,11 \\
\hline AKG $(\mathrm{mg} / \mathrm{dL})$ & $156,83 \pm 65,70(77-315)$ & $146,15 \pm 60,72(64-327)$ & 0,38 \\
\hline A1c (\%, mmol/mol) & $\begin{array}{l}8,23 \pm 2,50,66 \pm 20,04 \\
(5,5-15,4,37-145)\end{array}$ & $\begin{array}{l}7,42 \pm 1,79,58 \pm 13,99 \\
(5,3-12,7,34-115)\end{array}$ & 0,5 \\
\hline Total C (mg/dL) & $209,28 \pm 61,79(69-478)$ & $200,20 \pm 47,28(103-298)$ & 0,82 \\
\hline LDL-C (mg/dL) & $128,65 \pm 53,73(4-372)$ & $117,53 \pm 39,26(33-199)$ & 0,65 \\
\hline $\mathrm{TG}(\mathrm{mg} / \mathrm{dL})$ & $209,98 \pm 145,34(56-773)$ & $199,68 \pm 137,89(47-793)$ & 0,36 \\
\hline HDL-C (mg/dL) & $43,48 \pm 11,79(28-80)$ & $45,08 \pm 8,67(26-62)$ & 0,5 \\
\hline Fetuin-A (mg/L) & $368.49(176,61-496,25)$ & $408,10(216,59-882,51)$ & $0,008^{*}$ \\
\hline ADMA ( $\mu \mathrm{mol} / \mathrm{L})$ & $0,66 \pm 0,20(0,23-1,10)$ & $0,53 \pm 0,15(0,24-0,81)$ & $0,013^{*}$ \\
\hline
\end{tabular}

MAÜ: microalbüminüri, HT: hipertansiyon, VKi: vücut kitle indeksi, ABI: ankle-brakiyal indeks, AKG: açlık kan glukozu, Total C: total kolesterol, LDL-C: düşük dansiteli lipoprotein kolesterol, TG: trigliserit, HDL-C: yüksek dansiteli lipoprotein kolesterol, ADMA: serum asymmetric dimethyl arjinin.

Veriler standart sapma (SD) veya sayı ( $n$ ) olarak verilmiştir. İstatistiksel olarak anlamlı değerler * işareti ile gösterilmiştir $(p<0.05)$.

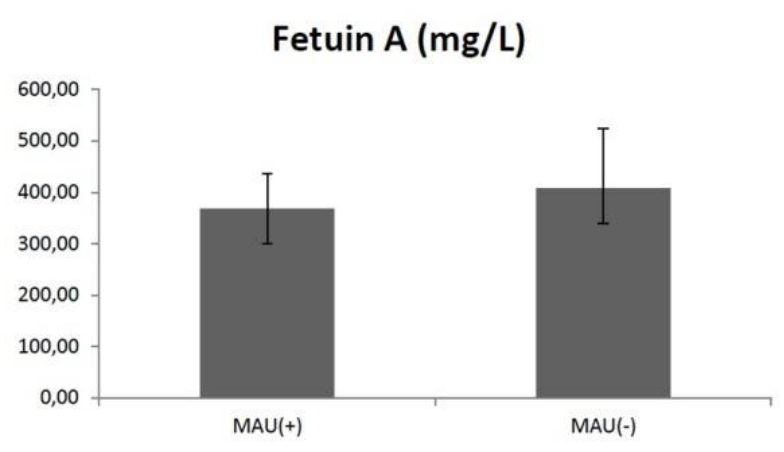

Şekil-1. Çalışma gruplarında fetuin-A düzeyleri.

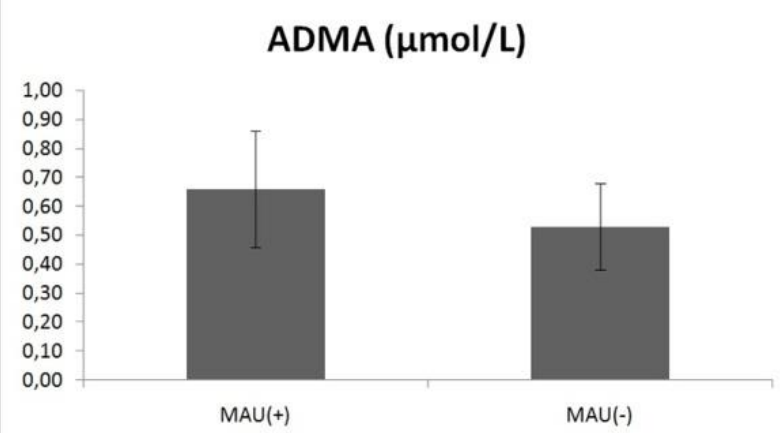

Şekil-2. Çalışma gruplarında ADMA düzeyleri. 


\section{Tartışma}

Mikroalbüminüri, son organ hasarının önemli bir göstergesidir ve T2DM hastalarında ateroskleroz belirteci olarak kullanılabilir (19). Bizim çalışmamızda, MAÜ olan ve olmayan T2DM hastalarında $A B I$, fetuin- $A, A D M A$, lipitler, $A 1 c$ ve AKG düzeyleri değerlendirildi. Çalışma sonunda T2DM ve MAÜ'lü hastalarda serum ADMA'nın aterosklerotik süreç için fetuin-A'dan daha üstün olduğu bulundu.

Insülin direnci, kan basıncı ve VKl'den bağımsız olarak, anormal albüminüri ile yüksek fetuin-A düzeyleri arasında anlamlı bir ilişki vardır (20). Ancak bizim çalışmamızda, bu çalışma sonucundan farklı olarak MAÜ'lü hastalarda fetuinA düzeyleri, MAÜ olmayanlara göre daha düşük saptandı. Literatürde çelişkili sonuçlar olması sebebiyle ve gelecekteki araştırmalara da yön vermek adına bir derlemede arteriyel kalsifikasyon ve kardiyovasküler hastalıklardaki fetuin-A'nın potansiyel rolü ve prognostik değeri tartışıımıştır (21). Bu derlemeye göre fetuin-A, bir yandan insülin reseptörü inhibitörü olması ve insülin direncini arttırması, adiposit disfonksiyonunda rol oynayan ve non-alkolik yağlı karaciğer hastalığıyla ilişkili bir protein olması sebebiyle aterosklerozu destekliyor gibi görünse de diğer yandan doku ve vasküler kalsifikasyonu inhibe etmesi sebebiyle aterosklerozda koruyucu bir faktör olarak rol oynar (21). Bu yüzden fetuin-A'nın kardiyovasküler hastalıklardaki rolü karmaşıktır. İnsan çalışmalarında yüksek fetuin-A düzeylerinin, visseral obezite ile ilişkili olduğu (22), yeni diyabet gelişme riskini arttırdığı (23) ve artmış fetuin-A düzeyleri olan hastalarda diyabet insidansının artmış olduğu (22) saptanmıştır. Bu durum fetuinA'nın ateroskleroza yol açabileceğini düşündürmektedir. Bunun yanı sıra in-vitro deneylerde, fetuin-A'nın, kalsiyum fosfatın çökmesini inhibe ettiği, azalmış serum fetuin- $A$ düzeylerinin ektopik kalsifikasyona yol açtığı saptanmıştır (11). Metabolik bozukluklarda genellikle yüksek fetuin-A seviyeleri görülürken, ilerlemiş ateroskleroz ise daha düşük fetuin- $A$ düzeyleri ile seyreden yoğun kalsifikasyona yol açar. Sonuçlar bu yüzden tartışmalıdır. Derlemede bahsedilen Lorant ve arkadaşlarının çalışmasında, diyabetik olan ve olmayan PAH hastalarında fetuinA düzeyleri daha yüksek (3), Szeberin ve arkadaşlarının çalışmasında ise $\mathrm{PAH}$ olan nonüremik hastalarda fetuin-A düzeyleri aterosklerozun şiddeti ile ters orantılıdır. Bu sonuç arteriyel kalsifikasyon gelişiminde fetuin-A için varsayılan koruyucu rolü desteklemektedir (23).
Derlemede bu tartışmalı sonuçları açıklarken atıfta bulunulan Mori ve arkadaşlarının çalışmasına göre, aterosklerozun başlangıcında fetuin-A düzeyleri artar, geç fazda ise daha düşük düzeylerde olup ve diyabet, böbrek fonksiyonları, ilaçlar ve diğer birçok faktör bu durumu etkileyebilmektedir (24).

İki çalışmaya göre, PAH olan T2DM hastalarında fetuin-A daha düşük düzeydedir $(14,25)$. Eraso ve arkadaşlarının çalışmasında, normal böbrek fonksiyonu olan, kardiyovasküler hastalığı olmayan $\mathrm{PAH}$ hastalarında fetuin-A düzeyleri daha düşüktür (14). Eleftheriadou ve arkadaşlarının çalışmasında, T2DM'lu hastalar, diyabetik olmayanlardan daha yüksek fetuin-A seviyelerine sahip, ayrıca T2DM ve $\mathrm{PAH}$ olan hastalar ise $\mathrm{PAH}$ olmayan diyabetik hastalardan daha düşük fetuin-A seviyelerine sahiptir. Tip 2 DM olan hastalarda fetuin-A düzeyleri $A B \mid$ ile ilişkilidir. Çok değişkenli analiz sonucu, T2DM'li hastalarda, uzun diyabet süresi, sigara, hipertansiyon ve dislipideminin yanı sıra düşük fetuin-A düzeyleri ile $\mathrm{PAH}$ olasılığının arttığı görülmektedir. Daha az şiddetli alt ekstremite arteriyel kalsifikasyonu olan olgularda daha yüksek fetuin-A seviyelerine doğru bir eğilim mevcuttur (25). Lorant ve arkadaşlarının çalışmasında; T2DM'li PAH olan hastalarda fetuin-A düzeyleri yüksektir (3). Bu sonuç bizim çalışmamızdaki fetuin- $A$ ve $A B I$ arasındaki ilişki ile uyumlu değildir.

Roos ve arkadaşlarına göre, diyabetik olmayan ve sağlıklı diyabetli vasküler hastalığı olmayan hastalarda, fetuin-A'nın daha yüksek düzeyde olması vasküler risklerle ilişkilidir. Bu farklı sonuç vaskülopatili hastalarda elde edilmiştir. $(4,26,27)$. Bizim çalışmamızda, fetuin-A düzeyleri ile MAÜ arasında anlamlı negatif korelasyona ek olarak, $A B I \leq 0,9$ olan hastalarda daha düşük fetuin-A düzeyleri saptandı.

Jirak ve arkadaşlarının çalışmasında, PAH olan hastalarda kardiyovasküler bir biyomarker olan fetuin-A düzeyleri düşüktür (28). Çalışmamızda da bu çalışma ile uyumlu olarak düşük fetuin-A düzeyleri ile $\mathrm{PAH}$ arasında anlamlı ilişki saptandı $(p=0,001)$.

Guo ve arkadaşlarına göre, MAÜ olan ve olmayan hastalarda; yaş, cinsiyet, VKİ, sigara içme öyküsü, diyabet süresi, A1c, AKG, LDL kolesterol, HDL kolesterol düzeyleri açısından anlamlı bir fark mevcuttu. Ancak total kolesterol, TG, alkol tüketimi ile MAÜ arasında anlamlı fark yoktu (29). Çalışmamızda ise diyabet süresi dışında diğer değişkenler ile MAÜ arasında anlamlı fark saptanmadı.

Birçok çalışmaya göre, diyabetik hastalarda MAÜ ile düşük $A B I$ arasında anlamlı bir ilişki mevcuttur 
(30-33). Bizim çalışmamızda ise MAÜ'lü 40 diabetik hastanın dokuzunda (\%22.5) düşük $A B \mid$ tespit edildi. Bununla birlikte, MAÜ ile düşük $A B \dot{I}$ arasında anlamlı bir ilişki olmadığı belirlendi $(p=0.11)$

Japonya'da yapılmış bir çalışmaya göre, T2DM'li hastalarda, yüksek ADMA düzeyleri yeni ve güçlü bir nefropati progresyonu belirleyicisi olabilir. Hem normo hem de MAÜ olan diyabetli hastalarda, serum ADMA düzeyleri ileri düzey albüminüri için prognostiktir (34). Bizim çalışmamızda da MAÜ ile ADMA düzeylerinin yüksekliği arasında istatistiksel olarak anlamlı bir ilişki tespit edildi $(p=0,013)$.

ADMA'nın kronik yüksekliği hayvanlarda aterosklerotik lezyonlara sebep olur (15); bu da ADMA'nın proteinürisi olan T2DM'li hastalarda ateroskleroz gelişiminde önemli bir rol oynayabileceği anlamına gelmektedir. Çalışmamızda da MAÜ pozitif T2DM'li hastalarda ADMA düzeylerinin yüksek olarak bulunması ADMA'nın ateroskleroz belirteci olabileceğini düşündürmektedir.

Bir çalışmaya göre, T2DM'li hastalarda iki yıllık takipte ADMA yüksekliği, artmış kardiyovasküler riskle ilişkilidir (35). Başka bir çalışmada da aterosklerotik vasküler hastalığı olmayan diyabetik hastalarla karşılaştıııldığında, aterosklerotik vasküler hastalığı olan diyabetik hastalarda ADMA düzeyi daha yüksektir (36). Özdoğan ve arkadaşlarına göre, T2DM'li hastalarda ADMA ve karotis intima media kalınlığı arasında anlamlı bir ilişki mevcuttur (37). Birçok çalışma sonucuna göre, karotis intima media kalınlığı erken aterosklerozun bir göstergesidir $(38,39)$. Karakoç ve arkadaşlarının çalışmasında ise vasküler komplikasyonu olan T2DM'li hastalarda vasküler komplikasyonu olmayan hastalara oranla daha düşük ADMA düzeyleri vardır, fakat bu iki grup arasında istatistiksel olarak anlamlı bir fark yoktur
(40). Bizim çalışmamızda PAH açısından bakılan $A B I$ ile ADMA arasında anlamlı bir ilişki olmamasına rağmen, MAÜ varlığı ile ADMA arasında anlamlı ilişki olması, diyabete bağlı vasküler komplikasyonlar ile ADMA arasında ilişki olabileceğini düşündürmektedir.

Glisemik kontrol ve nefropatinin, ADMA düzeylerini doğrudan etkileyebileceğini belirleyen bazı çalışmalar vardır $(34,41,42)$. Buna göre, ADMA düzeyleri hastalığın ilerlemesi ve komplikasyon durumu ile değişebilir ve bu nedenle diyabetlilerde ADMA'nın prognostik değeri, çalışma popülasyonuna göre değişebilir. $\mathrm{Bu}$ sonuç T2DM'de kardiyovasküler komplikasyonlar için ADMA'nın prognostik değeri ile ilgili çelişkili sonuçları açıklayabilir.

Çalışmamızda mikroalbüminüriyi değerlendirirken, 24 saatlik idrar toplanamamıştır. Sabah ilk idrar örneğindeki mikroalbümin/kreatinin oranı daha az hassas olsa da 24 saatlik üriner albümin atılımı ile uyumlu olduğu ve epidemiyolojik çalışmalarda güvenilir bir alternatif olabileceği bildirilmiştir (43).

\section{Sonuç}

Serum ADMA seviyeleri daha yüksek olmakla birlikte, MAÜ'lü T2DM hastalarında serum fetuin-A düzeyleri daha düşük olarak saptandı. Ayrıca MAÜ ve $A B \mid$ değerleri arasında anlamlı bir ilişki bulunamadı. Bu nedenle, ADMA'nın aterosklerotik süreçte MAÜ'lü T2DM'li hastalarda fetuin-A'dan daha üstün olduğu ileri sürülebilir.

Açıklama: Bu çalışma Ege Üniversitesi Bilimsel Araştırma Projeleri tarafından finanse edilerek desteklenmiştir (Sayı: 2015-TIP046). Tüm yazarlar kişisel veya finansal çıkar çatışması olmadığını beyan etmektedir. İstatistiksel analizlere katkılarından dolayı Araştırma Görevlisi Hatice Uluer'e teşekkür ederiz.

\section{Kaynaklar}

1. David KM. Definition of diabetes mellitus. In: Rose BD (ed). Uptodate. Wellesley: 2009: 17 (1). [Cited 26 May 2018]. Available from: http://www.uptodate.com.

2. St Clair L, Ballantyne CM. Biological surrogates for enhancing cardiovascular risk prediction in type 2 diabetes mellitus. Am J Cardiol 2007; 99: 80B-8B.

3. Lorant DP, Grujicic M, Hoebaus C, et al. Fetuin-A levels are increased in patients with type 2 diabetes and peripheral arterial disease. Diabetes care 2011; 34: 156-61.

4. Roos M, Oikonomou D, von Eynatten M, et al. Associations of fetuin-A levels with vascular disease in type 2 diabetes patients with early diabetic nephropathy. Cardiovascular diabetology 2010; 9: 48.

5. Mogensen CE. Microalbuminuria, blood pressure and diabetic renal disease: origin and development of ideas. Diabetologia 1999; 42: 263-85. 
6. Garg JP, Bakris GL. Microalbuminuria: marker of vascular dysfunction, risk factor for cardiovascular disease. Vascular medicine 2002; 7 (1): 35-43.

7. Dinneen SF, Gerstein HC. The association of microalbuminuria and mortality in non-insulin dependent diabetes mellitus: a systematic overview of the literature. Arch Intern Med 1997; 157: 1413-8.

8. Spittell JA Jr. Diagnosis and management of occlusive peripheral arterial disease. Curr Probl Cardiol 1990; 15: 1.

9. Resnick HE, Lindsay RS, McDermott MM, et al. Relationship of high and low ankle brachial index to all-cause and cardiovascular disease mortality: the Strong Heart Study. Circulation 2004; 109: 733-9.

10. Barclay L, Vega C. Fetuin-A linked with incident diabetes. JAMA 2008; 300: 182-8.

11. Schafer $C$, Heiss A, Schwarz A, et al. The serum protein alpha 2-Heremans-Schmid glycoprotein/fetuin-A is a systemically acting inhibitor of ectopic calcification. J Clin Invest 2003; 112: 357-66.

12. Stefan N, Hennige AM, Staiger H, et al. Alpha2-Heremans-Schmid glycoprotein/fetuin-A is associated with insulin resistance and fat accumulation in the liver in humans. Diabetes care 2006; 29: 853-7.

13. Hennige AM, Staiger $H$, Wicke $C$, et al. Fetuin- $A$ induces cytokine expression and suppresses adiponectin production. PLoS One 2008; 3 (3): 1765.

14. Eraso LH, Ginwala N, Qasim AN, et al. Association of lower plasma fetuin-A levels with peripheral arterial disease in type 2 diabetes. Diabetes care 2010; 33: 408-10.

15. Krzyzanowska K, Mittermayer F, Shnawa N, et al. Asymmetrical dimethylarginine is related to renal function, chronic inflammation and macroangiopathy in patients with type 2 diabetes and albuminuria. Diabet Med 2007; 24: 81-6.

16. Mancia G, Fagard R, Narkiewicz K, et al. 2013 ESH/ESC Guidelines for the management of arterial hypertension: the Task Force for the management of arterial hypertension of the European Society of Hypertension (ESH) and of the European Society of Cardiology (ESC). J Hypertens 2013; 31 (7): 1281-357.

17. Stone NJ, Robinson JG, Lichtenstein AH, et al. 2013 ACC/AHA guideline on the treatment of blood cholesterol to reduce atherosclerotic cardiovascular risk in adults: a report of the American College of Cardiology/American Heart Association Task Force on Practice Guidelines. Circulation 2014; 129 (2): $1-45$.

18. American Diabetes Association. Peripheral arterial disease in people with diabetes. Diabetes care 2003; 26: 3333-41.

19. Naidoo DP. The link between microalbuminuria, endothelial dysfunction and cardiovascular disease in diabetes. Cardiovascular journal of South Africa 2002; 13: 194-9.

20. Li M, Xu M, Bi Y, et al. Association between higher serum fetuin-a concentrations and abnormal albuminuria in middle-aged and elderly chinese with normal glucose tolerance. Diabetes care 2010; 33 (11): 2462-4.

21. Krisztián V, Károly C, László K. The role of fetuin-A in cardiovascular diseases. Orv Hetil 2013; 155 (1): 16-23.

22. Ix JH, Wassel CL, Kanaya AM, et al. Fetuin $A$ and incident diabetes mellitus in older persons. JAMA 2008; 300: 182-8.

23. Stefan N, Haring HU, Schulze MB. Association of serum fetuin A level and diabetes risk. JAMA 2008; 300: 2247-8.

24. Mori K, Emoto M, Inaba M. Fetuin A: A multifunctional protein. Recent patents on endocrine, metabolic \& immune drug discovery 2011; 5: 124-46.

25. Eleftheriadou I, Grigoropoulou P, Kokkinos A, et al. Association of plasma fetuin-a levels with peripheral arterial disease and lower extremity arterial calcification in subjects with type 2 diabetes mellitus. J Diabetes Complications 2017; 31: 599-604.

26. Stefan N, Fritsche A, Weikert C, et al. Plasma fetuin-A levels and the risk of type 2 diabetes. Diabetes 2008; 57: 2762-7. 
27. Weikert C, Stefan N, Schulze MB, et al. Plasma fetuin-a levels and the risk of myocardial infarction and ischemic stroke. Circulation 2008; 118: 2555-62.

28. Jirak P, Mirna M, Wernly $B$, et al. Analysis of novel cardiovascular biomarkers in patients with peripheral artery disease (PAD). Minerva Med doi: 10.23736/S0026-4806.18.05628-8.

29. Guo L, Cheng Y, Wang X, et al. Association between microalbuminuria and cardiovascular disease in type 2 diabetes mellitus of the Beijing Han nationality. Acta Diabetol 2012; 49 (1): 65-71.

30. Makhdoomi K, Mohammadi A, Yekta Z, Aghasi MR, Zamani N, Vossughian S. Correlation between ankle-brachial index and microalbuminuria in type 2 diabetes mellitus. Iranian journal of kidney diseases 2013; 7: 204-9.

31. Tseng $\mathrm{CH}$, Chong $\mathrm{CK}$, Tseng CP, Tai TY. The association between urinary albumin excretion and ankle-brachial index in elderly Taiwanese patients with type 2 diabetes mellitus. Age Ageing 2008; 37: 77-82.

32. Choi SW, Yun WJ, Kim HY, et al. Association between albuminuria, carotid atherosclerosis, arterial stiffness, and peripheral arterial disease in Korean type 2 diabetic patients. Kidney Blood Press Res 2010; 33: 111-8.

33. Cao JJ, Barzilay JI, Peterson D, et al. The association of microalbuminuria with clinical cardiovascular diseasemand subclinical atherosclerosis in the elderly: the Cardiovascular Health Study. Atherosclerosis 2006; 187: 372-7.

34. Hanai K, Babazono T, Nyumura I, et al. Asymmetric dimethylarginine is closely associated with the development and progression of nephropathy in patients with type 2 diabetes. Nephrol Dial Transplant 2009; 24: 1884-8.

35. Cavusoglu E, Ruwende C, Chopra V, et al. Relation of baseline plasma ADMA levels to cardiovascular morbidity and mortality at two years in men with diabetes mellitus referred for coronary angiography. Atherosclerosis 2010; 210 (1): 226-31.

36. Celik M, Cerrah S, Arabul M, Akalin A. Relation of asymmetric dimethylarginine levels to macrovascular disease and inflammation markers in type 2 diabetic patients. Journal of diabetes research 2014;2014:139215. doi: 10.1155/2014/139215.

37. Ozdogan O, Cekic B. Is there a correlation between plasma levels of asymmetric dimethylarginine (ADMA) levels and atherosclerosis in type 2 diabetes patients in Turkey? The Medical Bulletin of Sisli Etfal Hospital 2017; 51 (1): 63-70.

38. Lorenz MW, Markus HS, Bots ML, Rosvall M, Sitzer M. Prediction of clinical cardiovascular events with carotid intima-media thickness: a systematic review and meta-analysis. Circulation 2007; 115: 459-67.

39. Bernard S, Serusclat A, Targe F, et al. Incremental predictive value of carotid ultrasonography in the assessment of coronary risk in a cohort of asymptomatic type 2 diabetic subjects. Diabetes care 2005; 28: 1158-62.

40. Karakoç A, Sahin A, Polat ES, et al. Serum apelin and ADMA levels in type 2 diabetics with and without vascular complications. Diabetes \& metabolic syndrome 2016;10(2 Suppl 1):106-9.

41. Hsu CP, Hsu PF, Chung MY, Lin SJ, Lu TM. Asymmetric dimethylarginine and long-term adverse cardiovascular events in patients with type 2 diabetes: relation with the glycemic control. Cardiovascular diabetology 2014; 13: 156.

42. Paiva H, Lehtimaki T, Laakso J, et al. Plasma concentrations of asymmetric-dimethylarginine in type 2 diabetes associate with glycemic control and glomerular filtration rate but not with risk factors of vasculopathy. Metabolism 2003; 52 (3): 303-7.

43. Witte EC, Lambers Heerspink HJ, de Zeeuw D, Bakker SJ, de Jong PE, Gan-sevoort R. First morning voids are more reliable than spot urine samples to assess microalbuminuria. J Am Soc Nephrol 2009; 20: $436-43$. 